\title{
Physical, mechanical and thermal properties of low-density polyethylene reinforced with PET-coated SBS paperboard shavings applying different processing conditions
}

\author{
Julia Santos Venzon ${ }^{1}$, Atilano Antônio Vegini ${ }^{2}$, Jackson Roberto Eleotério ${ }^{3}$, \\ Lorena Benathar Ballod Tavares ${ }^{1}$
}

\footnotetext{
${ }^{1}$ Universidade Regional de Blumenau, Center of Technological Sciences, Graduate Program in Environmental Engineering, São Paulo Street, 3250, CEP: 89030-000, Blumenau, Santa Catarina, Brazil

${ }^{2}$ Universidade Regional de Blumenau, Center of Technological Sciences, Department of Chemical Engineering, São Paulo Street, 3250, CEP: 89030-000, Blumenau, Santa Catarina, Brazil

${ }^{3}$ Universidade Regional de Blumenau, Center of Technological Sciences, Department of Forest Engineering, São Paulo Street, 3250, CEP: 89030-000, Blumenau, Santa Catarina, Brazil

e-mail: julia.jsantos3@gmail.com
}

\begin{abstract}
Awareness about environmental problems has generated interest in the research for new materials in line with the sustainability principles. The recycling of industrial solid waste has contributed to the transformation of environmental liabilities into new products with added commercial value. In this study, the physical, mechanical and thermal properties of low-density polyethylene (LDPE) composites reinforced with polyethylene terephthalate (PET)-coated solid bleached sulfate (SBS) paperboard shavings were investigated according to composite formation process variables: preparation temperature, mean particle diameter of components and reinforcement concentration. Very few studies on the characterization of composites reinforced with PETcoated SBS paperboard shavings have been reported to date. The analyses were carried out based on standard methods published by the American Society for Testing and Materials. The results indicate an increase in the moisture content and water absorption occurred as a function of the increase in the reinforcement. With regard to the density, there was no significant influence of variations in the granulometry or concentration of the PET-coated SBS paperboard shavings. Composites formed with particles of $0.73 \mathrm{~mm}$ at $140{ }^{\circ} \mathrm{C}$ presented satisfactory tensile and flexural strength, compared with the values for the LDPE resin. Composites with $20 \%$ reinforcement formed by particles of $4.05 \mathrm{~mm}$ at $140{ }^{\circ} \mathrm{C}$ showed $14 \%$ improvement in impact resistance properties. The thermal analysis indicated that shavings degradation occurred at $190{ }^{\circ} \mathrm{C}$. Thus lower temperatures need to be applied in the processing of this composite material. The processing conditions of the composites resulted in different performance for each evaluated property. The use of the composite in manufacturing products must follow the process conditions that will provide to material the desirable level of properties for the best performance of the final product.
\end{abstract}

Keywords: Lignocellulosic fibers. Low-density polyethylene. Polymer-matrix composites. Sustainability.

\section{INTRODUCTION}

The concept of moving towards a sustainable society involves prioritizing products considering the environmental scope. In recent years, consumer demands on corporate commitment to society and nature have become increasingly important [1-4]. In the current economic scenario, recourse to environmentally correct alternatives has driven the business strategy of many entrepreneurs, and this has become a differential for competitiveness in the market [3-5]. Contemporary life, together with new technologies, has led to an expansion in the consumption of industrialized products, which are mostly marketed in primary, secondary and tertiary packaging. The production of greater amounts of packaging has, in turn, increased the generation of solid waste [6-9]. 
There are many types of packaging materials and a notable example is solid bleached sulfate (SBS) paperboard coated with polyethylene terephthalate (PET) [10], which is widely used for the packaging of food products. An example are ultra-frozen foods ready for consumption and semi-finished products. A single company can generate about 40 tons per month of waste from this type of packaging [10-11]. The change in consumer eating habits and preference for frozen ready meals stimulates the generation of solid waste from packaging. In the case of packaging produced with thermoformed plastics, the annual global production of these resins is approximately 335 million tons [12]. The disposal of packaging from this type of material, notably low-density polyethylene (LDPE) [13], generates environmental problems as a consequence to the low recyclability due to the presence of contaminants such as paints, varnishes and residues remaining in the post-consumer packaging [14-15].

The use of packaging waste comprised of lignocellulosic or polymeric material in the formulation of composites represents an environmental and economic activity of great potential application in engineering and can aid the development of new technologies. In the current scenario, many researchers in this area are focusing on the study of composites with a polymer matrix reinforced with a variety of cellulosic materials [13]. WEARN et al. [16] investigated the thermal and mechanical properties, as well as the morphological characteristics, of LDPE composites with different levels of coconut fiber (mass concentrations of 5\% and $10 \%$ ) chemically treated by alkaline extraction with sodium hydroxide. The mass fiber content had an influence on the mechanical properties, so that an increase in the mass coconut fiber content slightly reduced the tensile strength and caused an increase of around 100\% in the elastic modulus value of the composite. Through the results obtained by scanning electron microscopy (SEM), the treatment via alkaline extraction proved to be efficient for better fiber-matrix adhesion.

The effect of short fibers of Cortaderia selloana residues on the mechanical and thermal properties of the polyethylene matrix were studied by JORDA-VILAPLANA et al. [17]. Tensile and impact tests, differential scanning calorimetry and thermogravimetric analysis were performed. The addition of 15 to $30 \%$ (by weight) of fiber resulted in high elastic and flexural modulus values, without significant changes in the thermal degradation of the polymeric composite. INAI et al. [18] studied the effects of a polyethylene oxide compatibilizer agent on the formation of polyethylene matrix composites reinforced with cellulose nanocrystals. The composites modified by the compatibilizer showed increased elastic force, elastic modulus and tensile strength with up to $1.5 \%$ (by weight) reinforcement with cellulose nanocrystals. It was observed that the polyethylene had a higher degree of crystallinity in the modified samples.

FERREIRA et al. [19] assessed biodegradable composites based on poly(butylene adipate-co-terephthalate) (PBAT) reinforced with natural fibers (Croton lanjouwensis, Malvastrum tomentosum and Trema micrantha) from the Amazon forest. All composites showed greater elasticity modulus than neat polymer. Addition of Croton lanjouwensis increased $48 \%$ the elasticity modulus of the polymer, while the addition of the Malvastrum tomentosum and Trema micrantha increased 70 and $72 \%$ the elasticity modulus of the PBAT, respectively. JESUS et al. [20] studied the thermal properties of recycled polystyrene composites reinforced with $10 \%$ and $20 \%$ by weight of cellulose fiber from sugarcane bagasse. The results showed that the reinforcement improved the material stiffness, as well as promoting an increase in the thermal deflection temperature. The composites thermal stability was intermediate between the fiber and matrix, decreasing with the increase in the fiber content.

In order to reduce the negative impact of the disposal of waste from the packaging industry in the environment, this study was aimed at demonstrating the relationship between the physical, mechanical and thermal properties and the processing conditions used to prepare composites with a matrix of post-consumer low-density polyethylene (LDPE) packaging waste, reinforced with PET-coated SBS paperboard shavings from the thermoforming of frozen food packaging.

\section{MATERIAL AND METHODS}

\subsection{Materials}

In order to obtain the composites, a mixture of several pieces of post-consumer LDPE packaging was used as the polymer matrix and passed through the recycling process. This material was donated by a plastics recycling plant from Indaial, Santa Catarina state, Brazil. The composites reinforcement consisted of PET-coated SBS paperboard shavings from the thermoforming of frozen food packaging and provided by a graphics company in Blumenau, Santa Catarina state, Brazil. 


\subsection{Sample preparation}

The particle size classification of the LDPE waste sample was carried out in order to select the particles size used for the composite formation. This procedure was performed according to the ASTM D1921 [21] standard, on a sieve shaker (Marconi, MA750, Piracicaba, Brazil) whose the opening order $\left(\mathrm{a}_{\mathrm{n}}\right)$ for the assembly of the sieve towers (Solotest, model 2.2, São Paulo, Brazil) followed Eq. 1. The LDPE waste sample showed greater amount in the particle size range between $12 \mathrm{MESH}(1.70 \mathrm{~mm})$ and $14 \mathrm{MESH}(1.18 \mathrm{~mm})$, corresponding to the mean particle diameter of $1.44 \mathrm{~mm}$. The largest diameter of LDPE particles was between 4 MESH $(4.75 \mathrm{~mm})$ and $5 \mathrm{MESH}(3.35 \mathrm{~mm})$, corresponding to the mean particle diameter of $4.05 \mathrm{~mm}$. The smallest diameter was between $20 \mathrm{MESH}(0.85 \mathrm{~mm})$ and $28 \mathrm{MESH}(0.6 \mathrm{~mm})$, corresponding to the mean particle diameter of $0.73 \mathrm{~mm}$. The granulometry was considered as a process variable because the specific surface area of the particles has a strong influence on the interaction and dispersion of the reinforcement in the polymeric matrix [15]. In this way, the largest $(4.05 \mathrm{~mm})$, medium $(1.44 \mathrm{~mm})$ and smallest $(0.73 \mathrm{~mm})$ particle diameter found in the granulometric classification of the LDPE waste was selected for the composites formation. The LDPE waste and PET-coated SBS paperboard shavings were ground in a Willye-type knife mill (Tecnal, model TE-650, Piracicaba, Brazil). The sieve diameter at the mill outlet varied by 4, 12 and $20 \mathrm{MESH}$, according to the granulometric sizes required for forming the composite material. All the material ground was sieved according to the granulometric classification process mentioned above, in order to ensure the homogeneity of the mixture between LDPE waste and PET-coated SBS paperboard shavings.

$$
\mathrm{a}_{\mathrm{n}}=0.074 \times(\sqrt{2})^{\mathrm{n}}
$$

After the sieving process, known amounts of the material (weighed on a digital scale, Marte, model AD2000, São Paulo, Brazil) were obtained according to the percentages of matrix and reinforcement required for the composites. The compositions were: $80 \%$ LDPE and 20\% PET-coated SBS paperboard; 90\% LDPE and 10\% PET-coated SBS paperboard; and 100\% LDPE. The mass percentages for the composite materials were based on the research of GOLL et al. [22]. The authors investigated the characteristics of composites whose compositions varied between 10 and 30\% for PET-coated SBS paperboard shavings and 90 to $70 \%$ for the stretch film waste (LDPE) and concluded that reinforcement of PET-coated SBS paperboard above $20 \%$ hinder the extrusion process and composite homogeneity. Before the forming step, LDPE waste and PETcoated SBS paperboard shavings, in their respective concentrations, were deposited in a plastic container and stirred for 2 minutes to obtain a homogeneous material. Then, each mixture was distributed into the molds to produce the specimens according to the respective tests.

The samples were pressed in a hydraulic press (Marconi, model MA 098/AR15, Piracicaba, Brazil), at a pressure of 54.4 $\mathrm{MPa}$ with a temperature gradient. According to reports in the literature, the thermal degradation of cellulose starts at $200{ }^{\circ} \mathrm{C}[23]$ and the melting temperature of the LDPE varies between $110{ }^{\circ} \mathrm{C}$ and $135^{\circ} \mathrm{C}$ depending on its molecular structure [24]. Tests were carried out using the hydraulic press in order to verify the maximum temperature applicable without burning the PET-coated SBS paperboard and the minimum temperature that allows the fusion of the LDPE. In order to identify the influence of the process temperature on the response variables, the temperatures of $190{ }^{\circ} \mathrm{C}$ and $140{ }^{\circ} \mathrm{C}$ were established for the abovementioned conditions. An intermediate temperature of $165{ }^{\circ} \mathrm{C}$ was established. After cooling the material in the press to a temperature of $30^{\circ} \mathrm{C}$, the specimens were removed from the mold and subjected to the characterization tests, performed in triplicate.

\subsection{Sample characterization}

All tests performed for the composite characterization are shown in Table 1 together their respective ASTM Standards, parameters and response variables. For physical analysis, the samples were dried in oven with forced air circulation (Prolab, model SXCR40, São Paulo, Brazil) and the mass was measured on analytical balance (Shimadzu, model AUY220, Kyoto, Japan). The impact machine (EMIC, model Izod, São José dos Pinhais, Brazil) was used to measure the Izod impact. Tensile and flexural strength tests were performed on the universal testing machine (EMIC, model DL 30,000, São José dos Pinhais, Brazil). In the thermogravimetric analysis, the dynamic thermogravimetry technique was applied, in which the temperature variation is linear. The equipment used was the thermogravimetric analyzer (Shimadzu, model DTG - 60, Kyoto, Japan). The differential scanning calorimetry analysis was performed using a differential scanning calorimeter (Shimadzu, model DSC - 60, Kyoto, Japan). The glass transition temperature (Tg) and melt enthalpy $(\Delta \mathrm{HF})$ of each sample were obtained in this assay. The degree of crystallinity of these samples was calculated from the 
melting enthalpy results according to Eq. 2, where $\mathrm{X}_{\mathrm{LDPE}}$ corresponds to the mass fraction of the LDPE in the samples and $\triangle \mathrm{HC}$ is the crystallization enthalpy of the pure LDPE, which corresponds to $148.25 \mathrm{~J}^{-1} \mathrm{~g}^{-1}$ [25].

$$
\text { Degree of crystallinity }(\%)=\frac{\Delta \mathrm{H}_{\mathrm{F}}}{\mathrm{x}_{\mathrm{L}, \mathrm{PPR}} \times \Delta \mathrm{H}_{\mathrm{C} .}} \times 100
$$

Table 1: Analyses performed for the composite characterization according respective properties, ASTM Standards, parameters and response variables.

\begin{tabular}{|c|c|c|c|c|}
\hline $\begin{array}{l}\text { ANALYSIS } \\
\text { PROPERTY }\end{array}$ & TESTS & STANDARDS & PARAMETERS & $\begin{array}{l}\text { RESPONSE VARIA- } \\
\text { BLES }\end{array}$ \\
\hline \multirow{3}{*}{ PHYSICAL } & $\begin{array}{l}\text { Moisture con- } \\
\text { tent }\end{array}$ & ASTM D570 ${ }^{[26]}$ & $\begin{array}{l}\text { Sample dimensions: } 60 \times 60 \times 5 \mathrm{~mm} \\
\text { Drying: } 50^{\circ} \mathrm{C} \text { for } 24 \mathrm{~h} .\end{array}$ & $\begin{array}{c}\text { Moisture content } \\
(\%)\end{array}$ \\
\hline & $\begin{array}{l}\text { Water absorp- } \\
\text { tion }\end{array}$ & ASTM D570 ${ }^{[26]}$ & $\begin{array}{l}\text { Sample dimensions: } 60 \times 60 \times 5 \mathrm{~mm} \\
\text { Initial immersion in water: } 2 \mathrm{~h} \text {. } \\
\text { Final immersion in water: } 24 \mathrm{~h} .\end{array}$ & $\begin{array}{l}\text { Water absorp- } \\
\text { tion }(\%)\end{array}$ \\
\hline & Density & $\begin{array}{c}\text { ASTM } \\
\text { D1622M }\end{array}$ & Sample dimensions: 20x30x5 mm & Density $\left(\mathrm{g} \mathrm{cm}^{-3}\right)$ \\
\hline \multirow{3}{*}{ MECHANICAL } & $\begin{array}{l}\text { Izod impact } \\
\text { strength }\end{array}$ & ASTM D256 $6^{[28]}$ & Pendulum: $2.7 \mathrm{~J}$. & $\begin{array}{l}\text { Izod impact strength } \\
\left({\left.\mathrm{J} . \mathrm{m}^{-1}\right)}^{-1}\right.\end{array}$ \\
\hline & $\begin{array}{l}\text { Tensile } \\
\text { strength }\end{array}$ & ASTM D638 ${ }^{[29]}$ & $\begin{array}{l}\text { Applied speed: } 5 \mathrm{~mm} \cdot \mathrm{min}^{-1} \text {. } \\
\text { Load cell applied: } 10,000 \mathrm{~N} \text {. }\end{array}$ & $\begin{array}{c}\text { Tensile strength } \\
(\mathrm{MPa}) \\
\text { Modulus of elasticity } \\
(\mathrm{MPa})\end{array}$ \\
\hline & $\begin{array}{l}\text { Flexural } \\
\text { strength }\end{array}$ & ASTM D790 $0^{[30]}$ & $\begin{array}{l}\text { Speed: } 21.13 \mathrm{~mm} \cdot \mathrm{min}^{-1} \text {. } \\
\text { Load cell: } 10,000 \mathrm{~N} .\end{array}$ & $\begin{array}{l}\text { Flexural strength } \\
(\mathrm{MPa}) \\
\text { Modulus of elasticity } \\
(\mathrm{MPa})\end{array}$ \\
\hline \multirow{2}{*}{ THERMAL } & $\begin{array}{l}\text { Thermograv- } \\
\text { imetric analy- } \\
\text { sis }\end{array}$ & $\begin{array}{c}\text { ASTM } \\
\text { D3850 }\end{array}$ & $\begin{array}{l}\text { Heating rate: } 10{ }^{\circ} \mathrm{C} . \mathrm{min}-1 . \\
\text { Temperature range: } 0 \text { to } 800{ }^{\circ} \mathrm{C} \text {. } \\
\text { Nitrogen flow: } 100 \mathrm{~mL} \cdot \mathrm{min}-1 .\end{array}$ & $\begin{array}{l}\text { Thermal degrada- } \\
\text { tion profile }- \text { mass } \\
\text { loss }(\%) \text { versus } \\
\text { temperature }\left({ }^{\circ} \mathrm{C}\right) \\
\end{array}$ \\
\hline & $\begin{array}{l}\text { Differential } \\
\text { scanning } \\
\text { calorimetry }\end{array}$ & $\begin{array}{c}\text { ASTM } \\
\text { D3418 }\end{array}$ & $\begin{array}{l}\text { Heating rate: } 10{ }^{\circ} \mathrm{C} . \mathrm{min}-1 . \\
\text { Temperature range: } 0 \text { to } 600{ }^{\circ} \mathrm{C} \text {. } \\
\text { Nitrogen flow: } 100 \mathrm{~mL} . \mathrm{min}-1 .\end{array}$ & $\begin{array}{l}\text { Glass transition tem- } \\
\text { perature }\left({ }^{\circ} \mathrm{C}\right) \\
\text { Degree of crystal- } \\
\text { linity }(\%)\end{array}$ \\
\hline
\end{tabular}

\subsection{Experimental design}

In this study, a $3^{\mathrm{k}}$ full factorial experimental design was applied. It was based on the controllable factors of temperature, mean particle diameter and sample composition, at three levels of variation. The results obtained for each test were interpreted with the aid of statistical treatment using Statistica 10.0 software. ANOVA and Tukey's test were employed (5\% probability).

\section{RESULTS AND DISCUSSION}

\subsection{Moisture content of the composites}

The moisture content values for the LDPE composites reinforced with $10 \%$ and $20 \%$ of PET-coated SBS paperboard shavings and of the samples comprised of 100\% LDPE residue are shown in Figure 1, according to the thermal and granulometric variations used in the composite preparation process. 

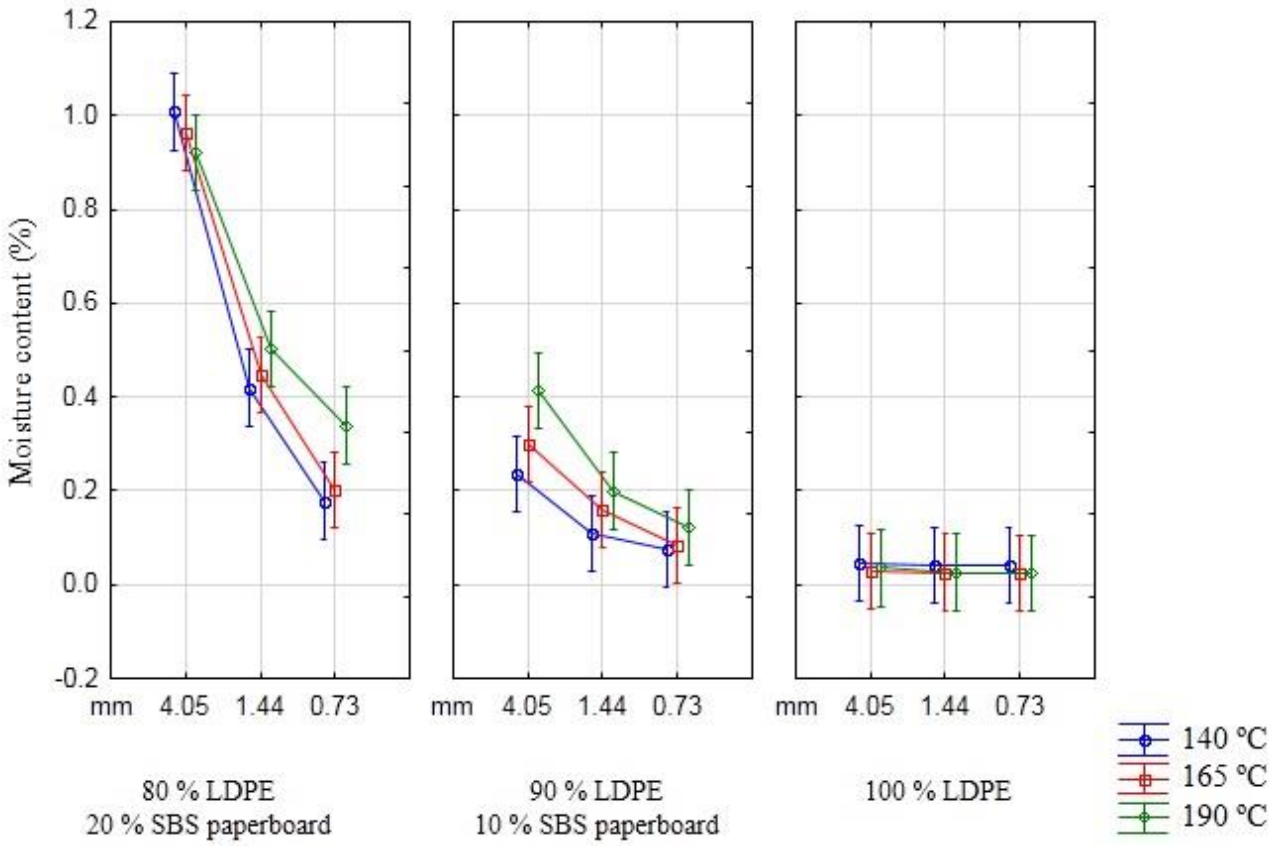

Figure 1: Moisture content for the LDPE composites reinforced with 10 and 20\% of PET-coated SBS paperboard shavings and for the samples formed by the LDPE residue, according to the thermal and granulometric variation used in the specimens formation process.

Significant differences between the moisture contents of the samples as a function of the process temperature were not observed. However, the granulometric size and the composition had a significant influence. No significant differences were noted in samples formed with LDPE resin. An increase in the moisture content with an increase in the reinforcement content was observed for the composites reinforced with PETcoated SBS paperboard shavings. This finding is associated with the SBS paperboard composition, consisting of $85 \%$ cellulose pulp, which is composed of cellulose, hemicellulose and lignin, compounds that favor the absorption of moisture [22,33]. Lignocellulosic fibers have hygroscopic characteristics due to the presence of hydroxyl groups in their structure. These groups form regions favorable to water adsorption, resulting in the destruction of the cell walls of the fibers and, consequently, the expansion of the composite material, reducing the interaction between the matrix and the fiber [15,33].

In relation to the granulometric scale, it was noted that the moisture content decreased with a reduction in the mean diameter of the particles used for the formation of the composites. This trend is even more pronounced for the specimens with 80\% LDPE and 20\% PET-coated SBS paperboard shavings, where significant differences for the three levels of granulometric variation were observed. Studies on the production of composites with lignocellulosic reinforcement have shown that the particle size is a factor that influences the saturation point of the composite moisture content. Particles with larger fibers tend to have higher levels of moisture content [34-36]. This could be because fibers of larger diameter are less likely to be completely surrounded by the matrix and thus the reinforcement particle surface is more accessible for contact with the water in the surrounding environment.

The composites formed by $80 \%$ LDPE and 20\% PET-coated SBS paperboard shavings with particles of $0.73 \mathrm{~mm}$, at temperatures of $140{ }^{\circ} \mathrm{C}$, did not present a significant difference in relation to the samples comprised with $100 \%$ LDPE residue. The same is true for samples prepared using particles with mean diameters of 1.44 and $0.73 \mathrm{~mm}$, at the three temperature levels, for the composition of 90\% LDPE and $10 \%$ shavings. Thus, for the reported conditions, it is possible to use the composite material in the manufacture of products made from LDPE without changes in the moisture content.

\subsection{Water absorption of the composites}

The results for the water absorption capacity of the LDPE composites reinforced with $10 \%$ and $20 \%$ of PETcoated SBS paperboard shavings and of samples comprised with only LDPE residue are shown in Figure 2, according to the thermal and granulometric variation employed in the specimen preparation process. 

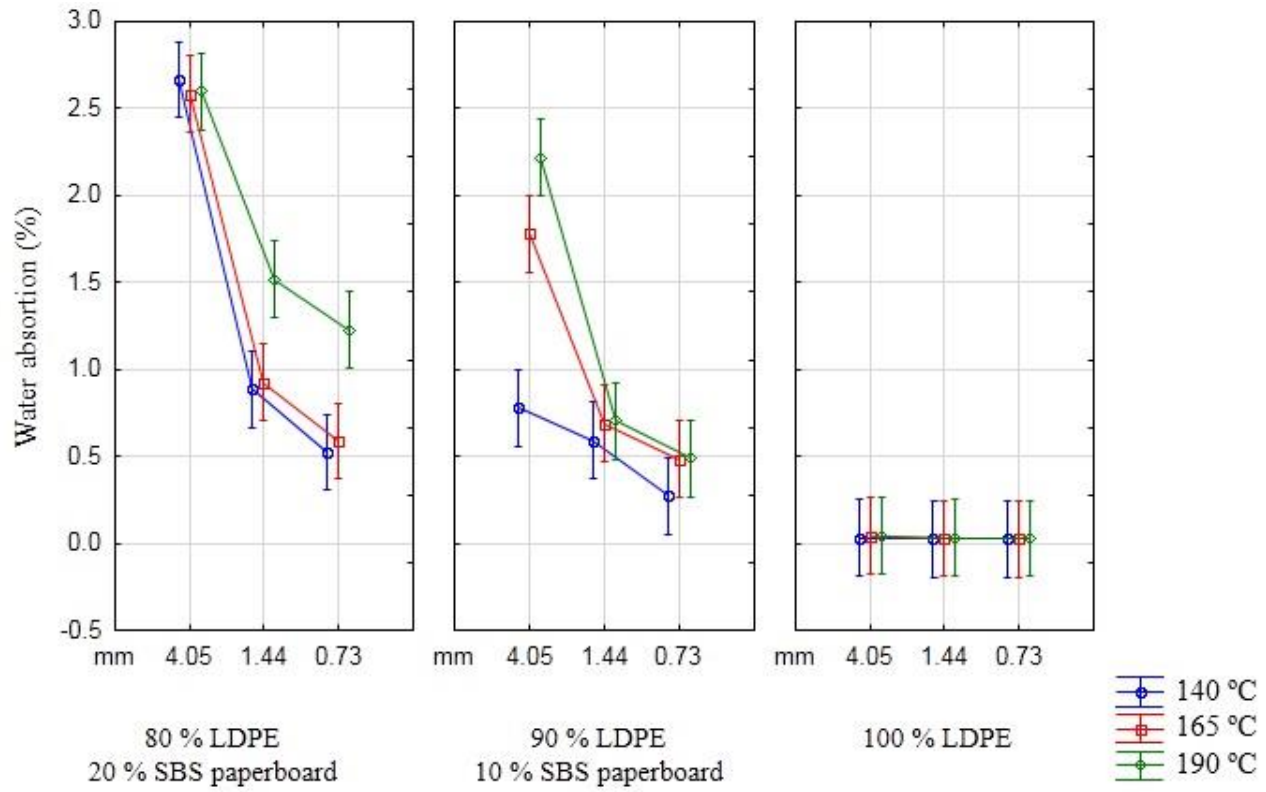

Figure 2: Water absorption for the LDPE composites reinforced with 10 and 20\% of PET-coated SBS paperboard shavings and for the samples formed by the LDPE residue, according to the thermal and granulometric variation used in the specimens formation process.

No significant differences were noted in samples formed with LDPE resin. There was a tendency toward a higher water absorption capacity with increase in the particles mean diameter and with greater reinforcement concentration in the samples. The same trend observed for the behavior of moisture content of composites, as shown in Figure 1. The higher the moisture content of the material, the greater its hydrophilic character, which indicates a greater possibility for water absorption. Other influencing factors are the contact surface area of the reinforcing particles and the extent to which the fibers are surrounded by the polymer [37].

For the composition 80\% LDPE and 20\% PET-coated SBS paperboard shavings, there was a significant difference for samples prepared using particles with mean diameters of 1.44 and $0.73 \mathrm{~mm}$, at a temperature of $190^{\circ} \mathrm{C}$, in relation to specimens obtained applying the other temperatures. For the samples with $90 \%$ LDPE and 10\% PET-coated SBS paperboard shavings with a mean diameter of $4.05 \mathrm{~mm}$, significant differences were observed between the results obtained for the three temperature levels applied. These findings suggest the degradation of the reinforcement as the temperature increases, particularly at $190{ }^{\circ} \mathrm{C}$, since the lignocellulosic materials have low thermal resistance and their degradation in the composite influences the void volume [38]. The composites obtained using particles with an average diameter of $0.73 \mathrm{~mm}$, with $90 \%$ LDPE and 10\% PET-coated SBS paperboard shavings, at the three temperature levels, did not present significant differences in relation to the samples comprised solely of the LDPE residue. The good dimensional stability attributed to the composites obtained with smaller particles guarantees greater homogeneity. Therefore, there are less inequalities that allow the absorption of water. In general, species with better stability also showed high internal bond strength, since good particle contact can reduce the penetration of moisture into the composite [35].

\subsection{Density of the composites}

The effects of the addition of $10 \%$ and $20 \%$ by mass of PET-coated SBS paperboard shavings in the composites, in relation to the density of the LDPE mixture, are shown in Figure 3, according to the thermal and granulometric variations applied in the specimen preparation process. 

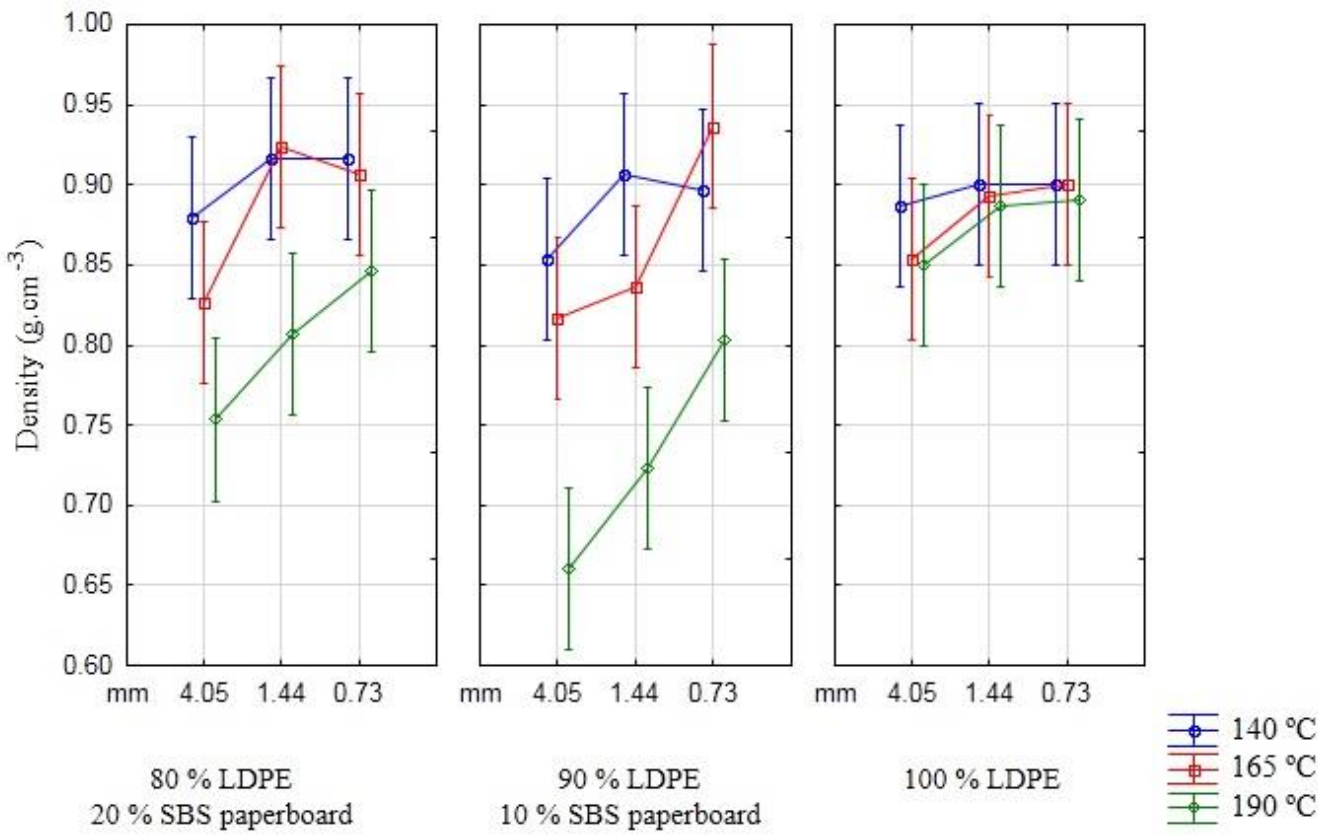

Figure 3: Density for the LDPE composites reinforced with 10 and 20\% of PET-coated SBS paperboard shavings and for the samples formed by the LDPE residue, according to the thermal and granulometric variation used in the specimens' formation process.

No significative variation in the density with an increasing amount of PET-coated SBS paperboard shavings in the LDPE mixture was observed. This can be attributed to the similar densities of cellulose pulp, the main component of SBS paperboard, and LDPE, which are approximately $0.8 \mathrm{~g}^{\mathrm{cm}} \mathrm{cm}^{-3}$ [39] and $0.9 \mathrm{~g} . \mathrm{cm}^{-3}$ [24], respectively. Regarding the mean particle diameter, there is a tendency for the density value to decrease with an increase in the size of the particles used to obtain the specimens, although the majority of the samples do not show a significant difference in relation to this factor. This trend is caused by the increase in the sample volume due to the increase in the diameter of the reinforcement particles, which interferes in the void index of the composite. Polymers tend to adhere better when shorter fibrous reinforcements are used [40, 41], causing a reduction in the sample void volume, which leads to higher density values. The results for density showed high standard deviation between samples. It could be due to a lack of homogeneity of mixture between reinforcement and matrix, generating differences between samples. The lack of homogeneity is one of the difficulties associated with preparing composites [22].

The temperature applied in the specimen preparation process also influenced the density values, which decreased as the temperature increased. Regarding this factor, significant differences were observed for most of the samples obtained at $190{ }^{\circ} \mathrm{C}$. Previous studies have shown that an increase in temperature leads to an increase in the LDPE plasticization, with a weakening of the interface between the reinforcement and the matrix [42]. The separation between these two phases facilitates the opening of the void fraction in the composite, decreasing its density [43]. This can be verified by observing the results in Figure 2, since the composites prepared at $190^{\circ} \mathrm{C}$ absorbed a greater amount of water, indicating a higher void fraction.

\subsection{Izod impact strength of the composites}

The results obtained for the Izod impact strength of the LDPE composites reinforced with $10 \%$ and $20 \%$ PET-coated SBS paperboard shavings and for samples comprised with only LDPE residue are shown in Figure 4 , according to the specified process conditions.

In general, a decrease in the impact resistance modulus was observed when the PET-coated SBS paperboard shavings were added to the LDPE resin, mainly for composites formed by smaller particles. This results from the low affinity between the matrix and the reinforcement caused by the hydrophilic character of the cellulose present in the SBS paperboard shavings, reducing the adhesion with the LDPE [44]. SEM images for LDPE composites reinforced with coconut fiber indicated a rough surface with cellulose exposure, whose high concentration in the fiber made it difficult to adhere with the polymeric matrix. The coupling of the fibrous material with LDPE was more efficient after chemical treatment of the fiber, which reduced its hydrophilic character [16]. The low surface adhesion in the composite causes the reinforcement particles to 
behave as points of stress concentration, facilitating the propagation of cracks [45]. In addition, it contributes to the appearance of void content in the sample, which reduces the mechanical properties of materials, even in small proportions [46]. SEM images of the HDPE composite surfaces with coconut and jute fibers without compatibilizer showed fractured surfaces induced by plastic deformation. The remaining fibers on the fractured surfaces created sites similar to crater holes, which proves the low adhesion of the fibers to the matrix material and provides mechanical failures [47]. Goll [48] highlighted images of LDPE composites reinforced with PET-coated SBS paperboard shavings and difficulties in the composites production that result in fibers agglomeration.
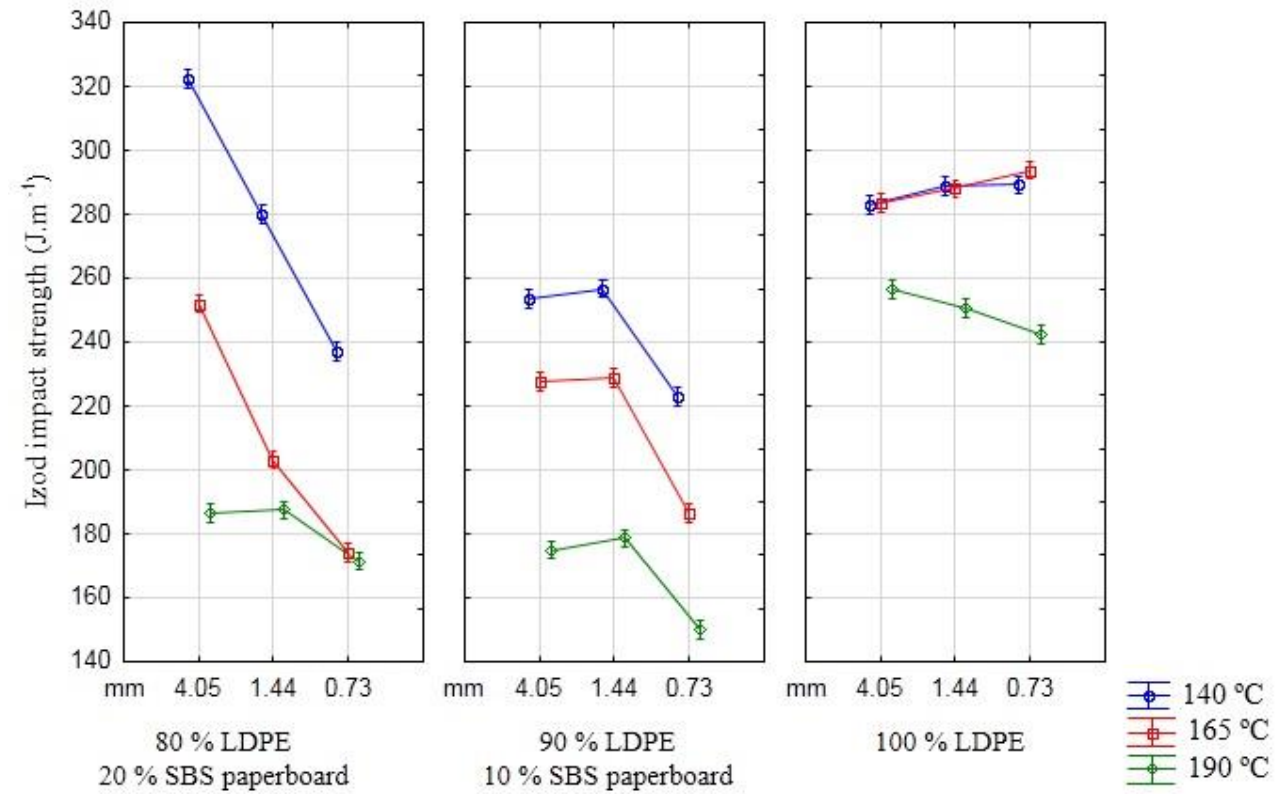

Figure 4: Results of the Izod impact strength for the LDPE composites reinforced with 10 and 20\% of PET-coated SBS paperboard shavings and for the samples formed by the LDPE residue, according to the thermal and granulometric variation used in the specimens formation process.

Regarding the composites obtained at the different temperatures, the impact resistance value was lowest for the samples containing particles with an average diameter of $0.73 \mathrm{~mm}$, and tended to increase for the particle size of $1.44 \mathrm{~mm}$. For most samples there was no significant difference between the composites comprised of particles with average diameters of $1.44 \mathrm{~mm}$ and $4.05 \mathrm{~mm}$, applying the same temperature. An exception occurred for the composite with 80\% LDPE and 20\% PET-coated SBS paperboard shavings obtained at a temperature of $140{ }^{\circ} \mathrm{C}$. When compared to pure LDPE under the same conditions, the specimens obtained with $1.44 \mathrm{~mm}$ particles did not present a significant difference and those with $4.05 \mathrm{~mm}$ particles showed a $14 \%$ improvement in relation to the impact resistance. Studies have shown that the shape and size of lignocellulosic fibers are also factors that influence the impact resistance of composites [37, 47]. This is because the mechanical force is dependent on the effective stress transfer between the reinforcement and the matrix. When the impact force is applied to the composite, the stress concentration causes the sample to rupture at the interface between these two phases. Thus, materials obtained using reinforcement with longer fibers can resist a greater impact force [37].

The preparation temperature also influenced the performance of the composites in relation to the impact resistance modulus, which decreased as the temperature used to prepare the test specimens increased. This effect was also significant for samples comprised of $100 \%$ LDPE obtained at $190{ }^{\circ} \mathrm{C}$. This phenomenon is associated with the temperature-induced plasticization of the polymer matrix, which leads to a reduction in the polymer glass transition temperature and, consequently, to changes in the mechanical properties of the composite material. Furthermore, it causes changes at the interface between the reinforcement and the polymer matrix, affecting the physical-chemical interactions between the resin and the fiber [42, 44]. Another possible explanation for these results is the thermal degradation of the reinforcement with a higher preparation temperature. The selection of the temperatures applied in this study was based on information available in the literature. It is reported that the thermal degradation of cellulose occurs at $200{ }^{\circ} \mathrm{C}$ [23]. However, tem- 
peratures above $180{ }^{\circ} \mathrm{C}$ result in the decomposition of biomass. Temperatures below this value are generally applied when a biomass material is used as reinforcement [49].

\subsection{Tensile testing of the composites}

The values for the tensile strength and elasticity modulus for the LDPE composites reinforced with $10 \%$ and $20 \%$ of PET-coated SBS paperboard shavings and for the samples comprised with only LDPE residue are shown in Figure 5, according to the specified processing conditions.
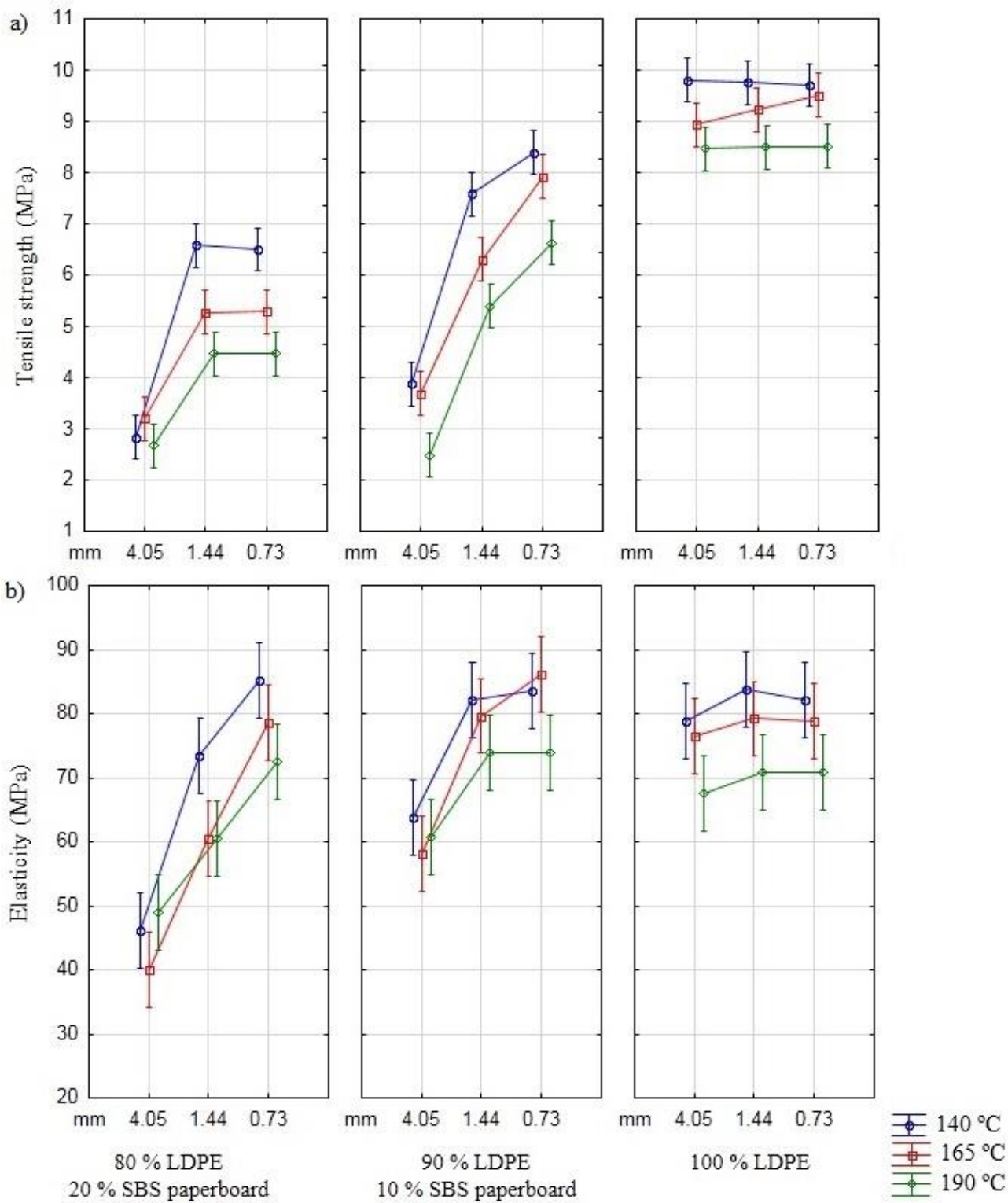

Figure 5: The a) tensile strength and b) modulus of elasticity for the LDPE composites reinforced with 10 and $20 \%$ of PET-coated SBS paperboard shavings and for the samples formed by the LDPE residue, according to the thermal and granulometric variation used in the specimens formation process.

It can be observed that the addition of PET-coated SBS paperboard to the LDPE resin decreased the tensile strength and elasticity modulus of the samples, indicating low stress transfer from the matrix to the reinforcement and greater stiffness of the composite in comparison with the polymer matrix. This is due to the lack of compatibility between the molecular structure of the hydrophilic fibrous reinforcement and the hydrophobic polymer matrix, which leads to poor interfacial adhesion. Studies have shown that the tensile strength and modulus of elasticity decrease significantly with increasing water uptake [50-52], which is in agreement with the results obtained in this study and reported in Figures 2 and 5. This finding has been at- 
tributed to the polymer matrix plasticization and to the weak interface between the fiber and the matrix [ 42 , $51]$.

The composites obtained using particles with a mean diameter of $4.05 \mathrm{~mm}$ showed the lowest tensile strength and the values varied significantly in comparison to the other granulometric indices. The tensile strength values for the samples with 90\% LDPE and 10\% PET-coated SBS paperboard shavings, obtained at temperatures of 165 and $190{ }^{\circ} \mathrm{C}$, also varied significantly when comparing the particle diameters of $1.44 \mathrm{~mm}$ and $0.73 \mathrm{~mm}$. In Figure $5 \mathrm{a}$, it can be observed that the tensile strength obtained for the composites produced at $140{ }^{\circ} \mathrm{C}$ with $4.05 \mathrm{~mm}$ particles is approximately $53 \%$ of the value obtained for samples prepared with particles of $0.73 \mathrm{~mm}$, for both reinforcement concentrations.

The increase in the grain size index also resulted in composites with a lower elasticity modulus. Previous studies have shown that the fiber length, diameter and direction affect the tensile properties of polymer composites, since the mechanical performance of these materials is strongly dependent on the amount of fibers aligned in the direction of the load applied [50,51]. These aspects were observed during the production of the specimens, and the homogeneity of the mixture and the orientation of the reinforcement in the direction of load applied were better when using particles with a mean diameter of $0.73 \mathrm{~mm}$. For the larger fibers, the distribution in different directions and the formation of agglomerates were evident, causing a lack of homogeneity between the reinforcement and matrix phases.

An increase in the temperature also decreased the tensile strength and elasticity of the samples. Although this was noted for the three temperatures studied, few significant variations were observed in this regard for the modulus of elasticity results. For the tensile strength, the difference was greatest between the samples prepared at $140{ }^{\circ} \mathrm{C}$ and $190^{\circ} \mathrm{C}$. The influence of temperature on the tensile properties is usually associated with the material that makes up the matrix [50]. In polymer composites, the fracture stress and modulus of elasticity decrease mainly when the glass transition temperature of the polymer is exceeded, causing the softening of the matrix and weakening of the interface between the composite phases [51,53]. The effects related to the preparation temperature and the decrease in tensile strength and elasticity of the studied composites can be attributed to the fact that the three temperatures used to obtain the test specimens exceeded the glass transition temperature of the LDPE resin $\left(136{ }^{\circ} \mathrm{C}\right.$, Figure 8a). However, the hypothesis that the fibers underwent thermal degradation at higher temperatures cannot be ruled out. This circumstance could lead to failures in the distribution of stresses in the composite.

\subsection{Flexural test of the composites}

The flexural strength and elasticity modulus for LDPE composites reinforced with 10\% and 20\% PET-coated SBS paperboard shavings and for samples comprised with 100\% LDPE are shown in Figure 6, according to the thermal and granulometric variations used in the preparation of the specimens.

The incorporation of PET-coated SBS paperboard shavings into the LDPE residue caused a reduction in the flexural strength and elasticity of the samples. This tendency is accentuated by the use of a larger mean particle diameter and higher temperature in the specimen preparation process. Similar observations have been reported by other researchers, who noted that biomass acts as a nucleating agent and reduces the elasticity and stress rupture of the material [49]. However, the samples containing $20 \%$ of reinforcement, obtained at $140{ }^{\circ} \mathrm{C}$ with particles of $0.73 \mathrm{~mm}$, diverged from the aforementioned tendency. In this case, on increasing the percentage of shavings, the flexural strength and elasticity modulus value did not differ significantly in relation to the values for the 100\% LDPE samples, under the same conditions. Samples formed with $20 \%$ reinforcement at $165^{\circ} \mathrm{C}$ and $0.73 \mathrm{~mm}$ showed no significant difference in relation to the flexural strength of those produced with $10 \%$ reinforcement, neither did they differ in terms of the elasticity module of the $100 \%$ LDPE samples, considering for both cases the same process conditions. The small size of the reinforcement particle used to obtain the samples contributed to these results.

The flexural strength values presented significant variations for the composites comprised of $4.05 \mathrm{~mm}$ particles in comparison with the other particle sizes, applying preparation temperatures of $140{ }^{\circ} \mathrm{C}$ and $165^{\circ} \mathrm{C}$. In Figure 6a, the composites produced at $140{ }^{\circ} \mathrm{C}$ with $10 \%$ reinforcement and $4.05 \mathrm{~mm}$ particles showed a reduction of approximately $14 \%$ in the flexural strength compared to those prepared with particles of 0.73 $\mathrm{mm}$. This reduction increased to $37 \%$ when the amount of reinforcement incorporated was $20 \%$. As previously noted in mechanical studies on other composites, these findings are related to the forces arising from the surface interaction between the composite phases [44]. Increasing the concentration of PET-coated SBS paperboard shavings and the use of larger particles may result in decreased homogenization between the matrix and the dispersed phase, affecting the mechanical properties of the composite material [52]. In addition, it is possible that fibers of larger diameter are not fully enveloped by the matrix. In this situation, the surface area 
of the large particles facilitates contact between the reinforcement and the environment, which can enhance the absorption of water and leads to a reduction in the mechanical properties of the materials [22, 36].

Regarding the temperature factor, significant variations occurred mainly for the samples produced at $190{ }^{\circ} \mathrm{C}$ in comparison with the other temperatures applied. In this condition, there were no significant differences according to the granulometric index used, except for the samples prepared with particles of $0.73 \mathrm{~mm}$ with $10 \%$ reinforcement. These results suggest that the temperature of $190{ }^{\circ} \mathrm{C}$ led to the thermal degradation of SBS paperboard shavings, which is also influenced by increases in the reinforcement concentration and mean particle diameter.
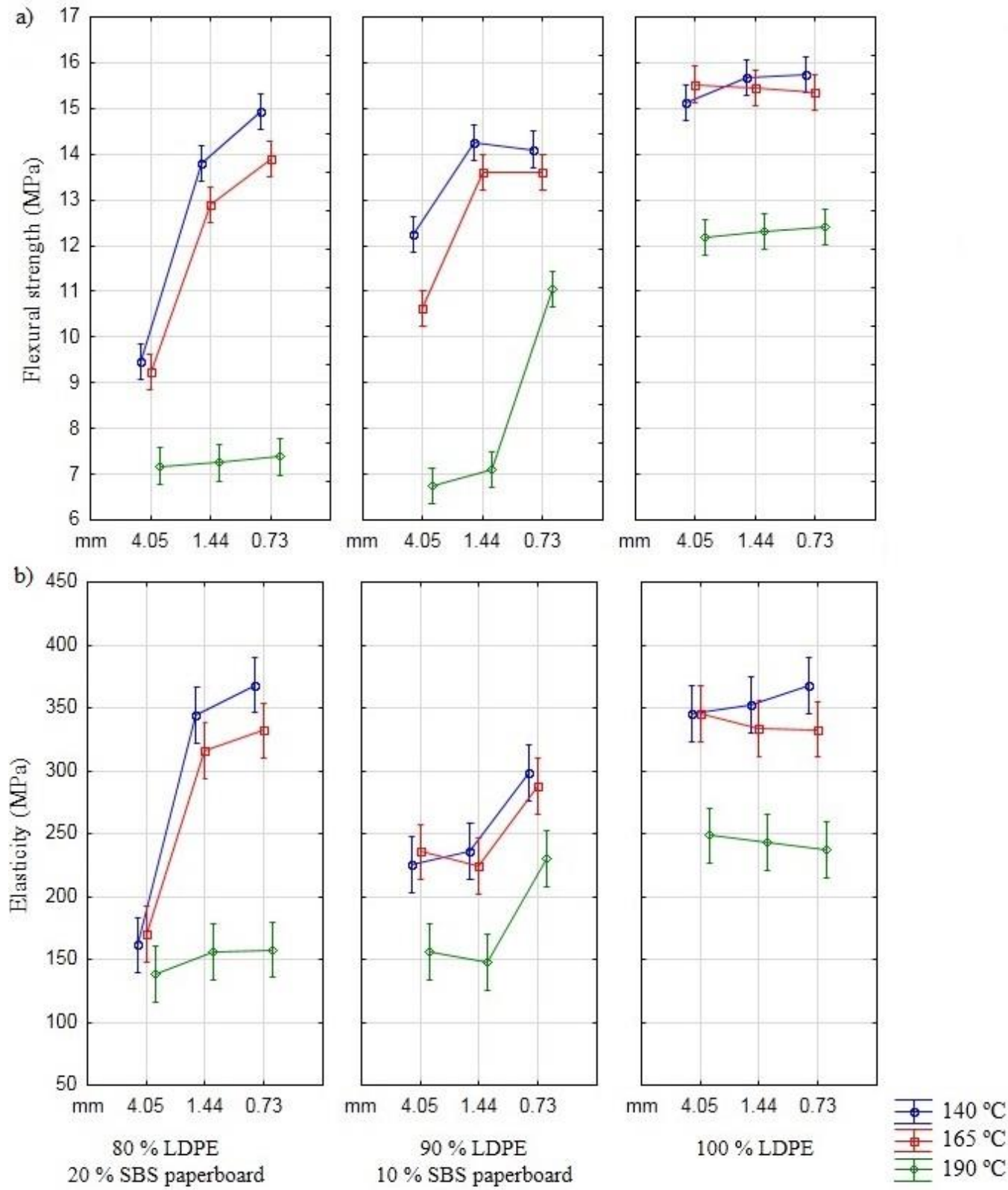

Figure 6: The a) flexural strength and b) modulus of elasticity for the LDPE composites reinforced with 10 and $20 \%$ of PET-coated SBS paperboard shavings and for the samples formed by the LDPE residue, according to the thermal and granulometric variation used in the specimens formation process.

For the composites prepared at $190{ }^{\circ} \mathrm{C}$, which resulted in the same range of values for the properties measured, the flexural strength and elasticity values were approximately $40 \%$ lower compared to the samples of $100 \%$ LDPE residue obtained under the same conditions. Based on this analysis, it can be assumed that the application of a higher temperature in the preparation of the composites leads to the degradation of the fibers. 
Therefore, it promotes the opening of voids in the sample making it more prone to the propagation of cracks $[38,46]$. The plasticization phenomenon of the polymer matrix also occurred [42], since the samples comprised of only LDPE residue produced at $190^{\circ} \mathrm{C}$ presented a significant variation in relation to the other specimens.

\subsection{Thermal gravimetric analysis}

The results for the thermal degradation of the LDPE composites reinforced with $10 \%$ and $20 \%$ PET-coated SBS paperboard shavings and the samples comprised of 100\% LDPE are shown in Figure 7, according to the thermal and granulometric variations applied in the preparation of the specimens.
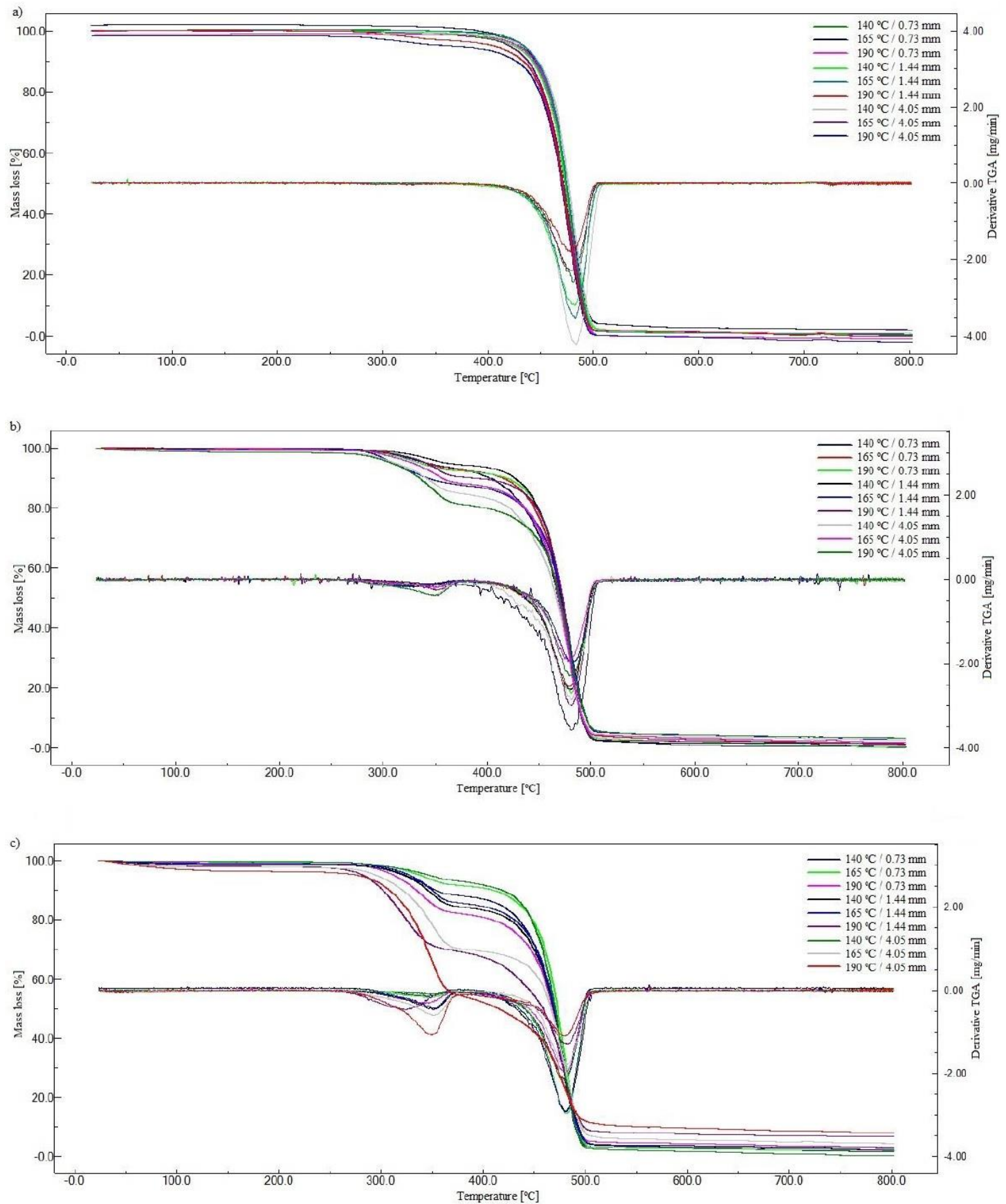

Figure 7: Thermal degradation profile and derivative curves of thermogravimetry for a) composites with $20 \%$ and b) $10 \%$ reinforced of PET-coated SBS paperboard shavings c) samples 100\% LDPE, according to the thermal and granulometric variation used in the specimens formation process. 
The thermal degradation profile for the samples obtained with 100\% LDPE (Figure 7a) showed that this polymer has stability in relation to its chemical structure until reaching a temperature of $400{ }^{\circ} \mathrm{C}$, where the mass loss of the specimens begins. However, for samples prepared at $190{ }^{\circ} \mathrm{C}$ with $4.05 \mathrm{~mm}$ and $1.44 \mathrm{~mm}$ particles, a deviation from the TGA curve was observed in comparison with the other specimens. Under these conditions, the degradation of the polymer began to occur at $300{ }^{\circ} \mathrm{C}$ and on reaching $400{ }^{\circ} \mathrm{C}$ a mass loss of around $10 \%$ was recorded. The degradation ended at $500{ }^{\circ} \mathrm{C}$ for all samples, with the mass loss reaching approximately $95 \%$.

The addition of PET-coated SBS paperboard shavings to the LDPE resin reduced the degradation onset temperature of the samples to $300{ }^{\circ} \mathrm{C}$. According to the results obtained for the composites with $10 \%$ (Figure $7 \mathrm{~b}$ ) and 20\% (Figure 7c) of reinforcement, it can be noted that the mass loss occurred in two stages: first from $300{ }^{\circ} \mathrm{C}$ to $350{ }^{\circ} \mathrm{C}$ and second from $400{ }^{\circ} \mathrm{C}$ to $500{ }^{\circ} \mathrm{C}$. The first stage is associated principally with the thermal degradation of the reinforcement, since for hemicellulose, cellulose and lignin occurs at between $200{ }^{\circ} \mathrm{C}$ and $500{ }^{\circ} \mathrm{C}$ [23]. The mass loss was most accelerated for the specimens prepared with particles of $4.05 \mathrm{~mm}$ at a temperature of $190{ }^{\circ} \mathrm{C}$. The second stage tends to be similar to the thermal degradation curves of the LDPE residue.

For the composites prepared with $10 \%$ PET-coated SBS paperboard shavings it was found that the degradation in the first stage is more accelerated for the samples obtained with particles of $4.05 \mathrm{~mm}$, followed by $1.44 \mathrm{~mm}$ and $0.73 \mathrm{~mm}$, and for the highest temperature followed by the lower temperatures. This indicates that the reinforcement particles with larger diameter are not easily surrounded by the polymer and are more conducive to interactions with the environment.

The results for the composites with $20 \%$ of reinforcement showed more clearly the influence of an increase in the temperature applied in the preparation of the specimens. For this composition, the samples obtained at $190^{\circ} \mathrm{C}$ showed more rapid degradation in the first stage. For the samples with particles of $4.05 \mathrm{~mm}$ the beginning of the degradation was recorded at $50{ }^{\circ} \mathrm{C}$ and there was a mass loss of $40 \%$ at $350{ }^{\circ} \mathrm{C}$. This result indicates that the use of a temperature at $190{ }^{\circ} \mathrm{C}$ during the preparation of the specimens may have caused damage to the composite reinforcement, which is aggravated by an increase in the average diameter of the particles, due to the contact surface expansion.

The most satisfactory results, when compared to LDPE residue, were obtained for the composites prepared at $140{ }^{\circ} \mathrm{C}$ with particles of $0.73 \mathrm{~mm}$, for both $10 \%$ and $20 \%$ of reinforcement. These presented only $5 \%$ of mass loss from the beginning of the degradation to $400{ }^{\circ} \mathrm{C}$. In this case, it can be affirmed that there was no degradation of the sample during its preparation and the reinforcement particles were surrounded by the matrix, because the composite follows the same trend with regard to its degradation as the pure polymer.

\subsection{Differential scanning calorimetry}

The effects of the addition of PET-coated SBS paperboard shavings (10 and 20\% by mass) on the thermal characteristics of the LDPE composites can be observed in Figure 8, according to the variations in thermal and granulometric parameters applied to the preparation of the specimens.

According to the results, the glass transition temperature (Tg) (Figure 8a) increased with the incorporation of the PET-coated SBS paperboard shavings into the LDPE residue. An increase in the Tg with the addition of reinforcement indicates an increasingly rigid interface in the composite, which is associated with stronger interfacial interactions and results in a decrease in the polymer chain mobility [54]. Falls in composites mechanical proprieties (as observed in the Figures 4, 5 and 6) may be related to this fact, since high rigidity reduces the elastic aspect of the material [51, 53].

Composites obtained with $10 \%$ reinforcement, at $140{ }^{\circ} \mathrm{C}$ and $165^{\circ} \mathrm{C}$ and particles of 0.28 and 1.44 $\mathrm{mm}$ presented $\mathrm{Tg}$ close to $138^{\circ} \mathrm{C}$. Similar result was observed for composites of $20 \%$ reinforcement, at 140 ${ }^{\circ} \mathrm{C}$, with particles of 0.28 and $1.44 \mathrm{~mm}$, as well as for $165{ }^{\circ} \mathrm{C}$ with $0.28 \mathrm{~mm}$. The resulting $\mathrm{Tg}$ is lower than the lowest processing temperature used in the composites manufacture. Thermal stresses inside the composites can result from the heating process of the samples above the $\mathrm{Tg}$ value, causing problems in the mechanical performance of the material.

The $\mathrm{Tg}$ value decreased when particles with a mean diameter of $4.05 \mathrm{~mm}$ were used to obtain the composites. This indicated that in composites prepared with particles of $4.05 \mathrm{~mm}$ there are weak interactions between the matrix and the reinforcement. Samples prepared at $190{ }^{\circ} \mathrm{C}$ gave lower $\mathrm{Tg}$ values when compared to the samples obtained at the other temperatures. In this case, the weak interactions between the composite phases can be associated with the degradation of the SBS paperboard shavings during the preparation of specimens and with the effect by plasticization, which degrades the Tg, as well as the strength and stiffness of the composite [42]. 
The values obtained for the crystallinity degree (Figure 8b) increased when the PET-coated SBS paperboard shavings were incorporated into the LDPE residue, accompanied by a slight decrease with increasing size of the particles used to prepare the specimens. The variation in the composition of the lignocellulosic fibers may lead to different effects on the inhibition of the thermal mobility of the polymer chains [55]. For those with lignin and hemicellulose content, an increase in the nucleation effect is observed, due to the fiber viscosity characteristics, which increase the crystallization degree of the polymer composite [54]. Accordingly, it has been postulated that PET-coated SBS paperboard shavings have the ability to modify the crystallization of the composite by increasing the nucleation area of LDPE, resulting in increased crystallinity. The decrease in the crystallinity degree with increasing particle diameter used to prepare the specimens is associated with relatively long fibers having little nucleation capacity due to the low interaction between the composite phases [56].
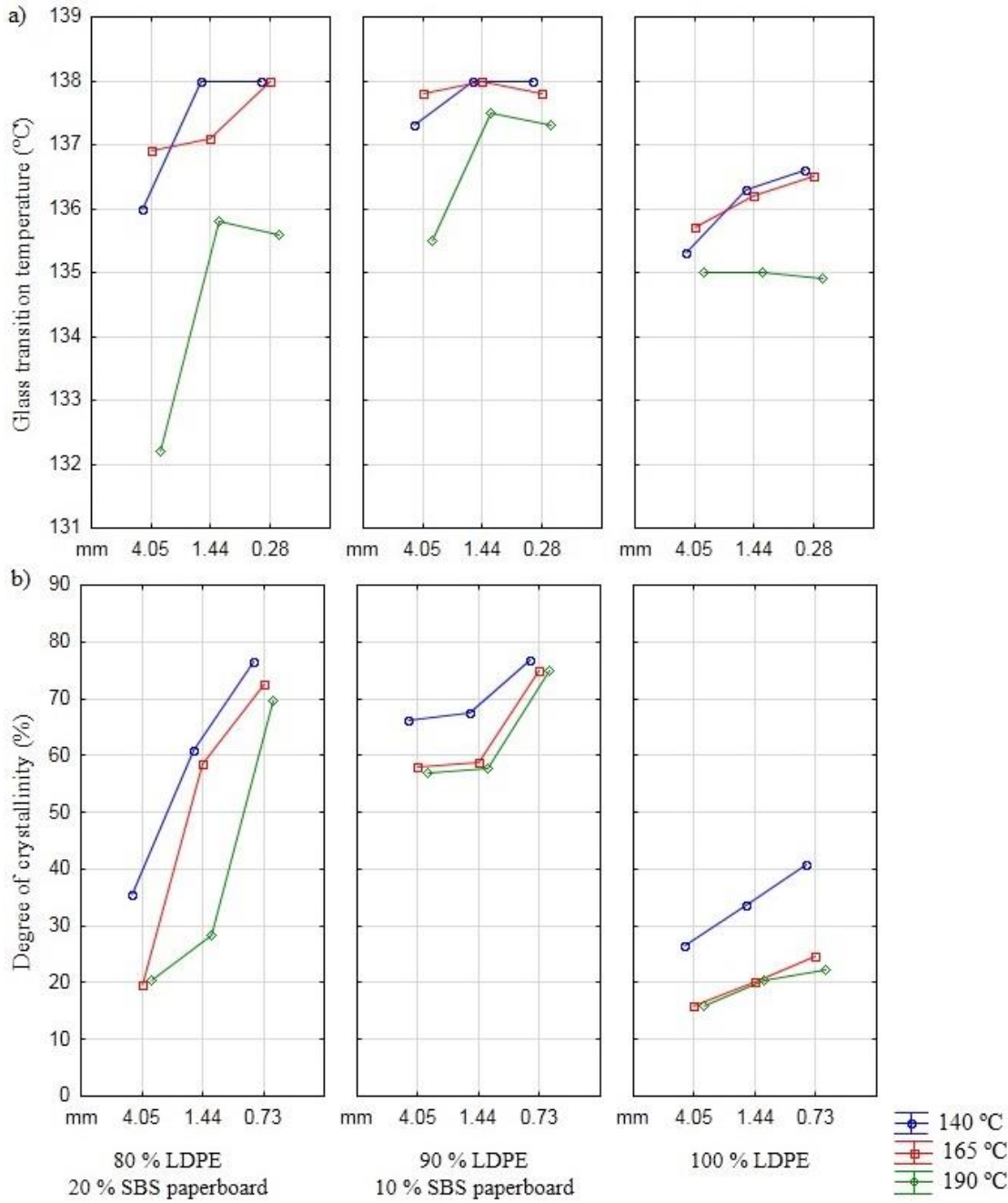

Figure 8: Results of a) glass transition temperature b) degree of crystallinity for the LDPE composites reinforced with 10 and $20 \%$ of PET-coated SBS paperboard shavings and for the samples formed by the LDPE residue, according to the thermal and granulometric variation used in the specimens formation process.

\section{CONCLUSIONS}

Composites of LDPE residues reinforced with PET-coated SBS paperboard shavings (in mass proportions of $10 \%$ and $20 \%$ ) were obtained varying the temperature applied in the preparation of the specimens and using three different average particle diameters. The use of larger particle diameters and higher amount of reinforcement in the composites formulation increased the moisture content and water absorption by composites. However, the composites did not show high values for these properties. With regard to the density, there was no significant variation in this property according to the amount of PET-coated SBS paperboard shavings in the composite or their particle size. Composites processed at temperature of $190{ }^{\circ} \mathrm{C}$ resulted in a decrease in the density of the specimens obtained. 
Regarding the mechanical properties, the average particle diameter and the sample preparation temperature were the main factors that influenced the performance of the composites. Composites obtained with particles of $0.73 \mathrm{~mm}$ at $140{ }^{\circ} \mathrm{C}$ presented satisfactory tensile and flexural strength values compared to the LDPE resin samples obtained under the same conditions. However, an increase in the reinforcement concentration and the use of particles with a larger diameter led to an improvement in the impact strength. For composites with $20 \%$ reinforcement with a particle size of $4.05 \mathrm{~mm}$, obtained at a temperature of $140{ }^{\circ} \mathrm{C}$, the impact strength was $14 \%$ higher than the value for samples obtained with $100 \%$ LDPE residue. The thermal analysis indicated that at $190{ }^{\circ} \mathrm{C}$ degradation of the SBS paperboard shavings in the composite occurs, and thus temperatures below this are recommended for the processing of this material.

The results of this study uphold the hypothesis that PET-coated SBS paperboard shavings can be incorporated into a low density polyethylene matrix without compromising its physical, mechanical and thermal properties when the composite is produced under the appropriate conditions. Furthermore, it was observed that the processing conditions (temperature, mean particle diameter and reinforcement concentration) affect the performance results for the physical, mechanical and thermal properties evaluated. Thus, prior to the manufacturing of products comprised of LDPE and PET-coated SBS paperboard shavings, it is important to select the process conditions that will provide a material with the properties that will ensure the best performance of the final product.

\section{ACKNOWLEDGEMENTS}

This work was supported by the Brazilian Ministry of Science, Technology, Innovation and Communication (MCTIC) [grant number 402593/2013-8], the National Council for Scientific and Technological Development (CNPq) [grant number 309903/2016-05] and the Brazilian State Funding Agency (FAPESC) [grant number 6688/2010-05].

\section{BIBLIOGRAPHY}

[1] KENIG-WITKOWSKA, M., "The concept of sustainable development in the European Union policy and law", Journal of Comparative Urban Law and Policy, https://readingroom.law.gsu.edu/jculp/vol1/iss1/6. v. 1, n. 1, pp. 64-80, 2017.

[2] HAMID, S., IJAB, M.T., SULAIMAN, H., et al., "Norman, Social media for environmental sustainability awareness in higher education," Int. J. Sustainability in Higher Education, https://doi.org/10.1108/IJSHE01-2015-0010. v. 18, n. 4, pp. 474-491, 2017.

[3] BOONS, F., LÜDEKE-FREUND, F., "Business models for sustainable innovation: state-of-the-art and steps towards a research agenda", J. Clean. Prod., https://doi.org/10.1016/j.jclepro.2012.07.007. v. 45, pp. 919, 2013.

[4] VENZON, J.S., NORILER, I.L.M., TAVARES, L. B. B., Roteiro para elaboração de um plano de negócios, 1 ed., Vila Nova de Gaia, Euedito, 2017.

[5] LINDER, M., BJÖRKDAHL, J., LJUNGBERG, D., "Environmental orientation and economic performance: a quasi-experimental study of small Swedish firms", Bus. Strategy Environ., http://onlinelibrary.wiley.com/doi/10.1002/bse.1788/full. v. 23, n. 5, pp. 333-348, 2014.

[6] BUCCI, D.Z., TAVARES, L.B.B., SELL, I., "Biodegradation and physical evaluation of PHB packaging”, Polym. Test., v. 26, n. 7, pp. 908-915, 2007. https://doi.org/10.1016/j.polymertesting.2007.06.013

[7] SEN, S.K., RAUT,S., "Microbial degradation of low density polyethylene (LDPE): A review", Journal of Environmental Chemical Engineering, https://doi.org/10.1016/j.jece.2015.01.003, v. 3, n. 1, pp. 462-473, 2015.

[8] HELLER, M.C., SELKE, S.E., KEOLEIAN, G.A., "Mapping the influence of food waste in food packaging environmental performance assessments", J. Ind. Ecology, https://doi.org/10.1111/jiec.12743, 2018.

[9] RUBIO, S., RAMOS, T.R.P., LEITÃO, M.M.R., et al., "Effectiveness of extended producer responsibility policies implementation: The case of Portuguese and Spanish packaging waste systems", J. Clean. Prod., https://doi.org/10.1016/j.jclepro.2018.10.299, v. 210, pp. 217-230, 2019.

[10] FERRI, G.N., HERMANN, K.L., WISBECK, E., et al., "Evaluación de la influencia de los factores físicos y nutricionales en la propagación del micelio de Pleurotus sajor-caju ccb-019 en biomasa residual de embalaje de alimentos", Rev. CSBEA, http://revistas.udesc.br/index.php/revistacsbea/article/view/6756/4606. v. 1, n. 1, pp. 1-6, 2015. 
[11] WORLD PACKAGING ORGANISATION, 2008. Position Paper-market Trends and Developments. www.worldpackaging.org (Accessed 12 March 2020).

[12] PLASTICS EUROPE - Association of Plastics Manufactures. Plastics - the facts 2017. Belgium, 2018. https://www.plasticseurope.org/application/files/5715/1717/4180/Plastics_the_facts_2017_FINAL_for_websi te_one_page.pdf (Accessed 08 October 2019).

[13] HORODYTSKA, O., VALDÉS, F.J., FULLANA, A., "Plastic flexible films waste management - A state of art review", Waste Management, 2018. https://doi.org/10.1016/j.wasman.2018.04.023.

[14] DILKES-HOFFMAN, L.S., LANE, J.L., GRANT, T., et al., "Laycock, Environmental impact of biodegradable food packaging when considering food waste", J. Clean. Prod., https://doi.org/10.1016/j.jclepro.2018.01.169. v. 180, pp. 325-334, 2018.

[15] MEHMANDOST, N., SORIANO, M.L., LUCENA, R., et al., "Recycled polystyrene-cotton composites, giving a second life to plastic residues for environmental remediation", Journal of Environmental Chemical Engineering, https://doi.org/10.1016/j.jece.2019.103424. v. 7, n. 5, pp. 103424, 2019.

[16] WEARN, Y.N., MONTAGNA, L.S., PASSADOR, F.R., "Compósitos de fibra de coco/LDPE: efeito do tratamento superficial das fibras de coco em compósitos verdes", https://doi.org/10.1590/s1517707620200001.0873. Matéria, v. 25, n. 1, 2020.

[17] JORDÁ-VILAPLANA, A., CARBONELL-VERDÚ, A., SAMPER, M.D., et al., "Development and characterization of a new natural fiber reinforced thermoplastic (NFRP) with Cortaderia selloana (Pampa grass) short fibers", http://dx.doi.org/10.1016/j.compscitech.2017.03.036. Comp. Sci. Technol., v. 145, pp. 1$9,2017$.

[18] INAI, N.H., LEWANDOWSKA, A.E., GHITA, O.R., et al., "Interfaces in polyethylene oxide modified cellulose nanocrystal-polyethylene matrix composites", https://doi.org/10.1016/j.compscitech.2017.11.009.

Comp. Sci. Technol., v. 154, pp. 128-135, 2018.

[19] FERREIRA, F.V., PINHEIRO, I.F., MARIANO, M., et al., "Environmentally friendly polymer composites based on PBAT reinforced with natural fibers from the amazon forest",

https://doi.org/10.1002/pc.25196. Polymer Composites, 2019.

[20] JESUS, L.C.C., LUZ, S.M.D., LEÃO, R.M., et al., "Comportamento térmico de compósitos de poliestireno reciclado reforçado com celulose de bagaço de cana", https://doi.org/10.1590/s1517-

707620190003.0736. Matéria, v. 24, n. 3, 2019.

[21] AMERICAN SOCIETY FOR TESTING AND MATERIALS. ASTM D1921: Standard Test Methods for Particle Size (Sieve Analysis) of Plastic Materials, 2012. https://www.astm.org/Standards/D1921.htm.

[22] GOLL, M.F.G. H., VENZON, J.S., VEGINI, A.A., et al., "Composites based on low-density polyethylene combined with PET-coated SBS paperboard shavings", https://doi.org/10.1590/s1517-

707620180004.0582. Matéria, v. 23, n. 4, 2018.

[23] DE MELO, R.P., MARQUES, M.F., NAVARD, P., et al., "Degradation studies and mechanical properties of treated curaua fibers and microcrystalline cellulose in composites with polyamide 6", https://doi.org/10.1177/0021998317690446. Journal of Composite Materials, v. 25, pp. 3481-3489, 2017.

[24] KEATING, M., LEE, I.H., WONG, C.S., "Thermal fractionation of ethylene polymers in packaging applications", https://doi.org/10.1016/0040-6031(96)02891-2. Thermochimica Acta, v. 284, n. 1, pp. 47-56, 1996.

[25] MARTIENSSEN, W., WARLIMONT, H., Springer Handbook of Condensate Matter and Materials Data. Hardcover: 1121 p., 2005.

[26] AMERICAN SOCIETY FOR TESTING AND MATERIALS. ASTM D570: Standard Test Method for Water Absorption of Plastics, 2010. http://www.astm.org/Standards/D570.

[27] AMERICAN SOCIETY FOR TESTING AND MATERIALS. ASTM D1622M: Standard Test Method for Apparent Density of Rigid Cellular Plastics, 2014. www.astm.org/Standards/D1622.

[28] AMERICAN SOCIETY FOR TESTING AND MATERIALS. ASTM D256: 2010. Standard Test Method for Determine the Izod Pendulum Impact Resistance of Plastics, 2010. www.astm.org/Standards/D256.

[29] AMERICAN SOCIETY FOR TESTING AND MATERIALS. ASTM D638: Standard Test Method for Tensile Properties of Plastics, 2014. https://www.astm.org/Standards/D638.htm. 
[30] AMERICAN SOCIETY FOR TESTING AND MATERIALS. ASTM D790: Standard Test Methods for Flexural Properties of Unreinforced and Reinforced Plastics and Electrical Insulating Materials, 2015. https://www.astm.org/Standards/D790.htm.

[31] AMERICAN SOCIETY FOR TESTING AND MATERIALS. ASTM D3850: Standard Terminology for Rapid Thermal Degradation of Solid Electrical Insulating Material by Thermogravimetric Analysis (TGA), 2012. https://www.astm.org/Standards/D3850.htm.

[32] AMERICAN SOCIETY FOR TESTING AND MATERIALS. ASTM D3418: Standard Test Method for Transition Temperatures and Enthalpies of Fusion and Crystallization of Polymers by Differential Scanning Calorimetry, 2015. https://www.astm.org/Standards/D3418.htm.

[33] SILVA, C.C., FREIRE JÚNIOR, R.C.S., FORD, E.T.L.C., et al., "Mechanical behavior and water absorption in sisal/glass hybrid composites", https://doi.org/10.1590/s1517-707620180004.0580. Matéria, v. 23, n. 4, 2018.

[34] FERNANDES, E.M., CORRELO, V.M., MANO, J.F., et al., "Polypropylene-based cork-polymer composites: processing parameters and properties", http://dx.doi.org/10.1016/j.compositesb.2014.05.019. Comp. Part B, v. 66, pp. 210-223, 2014.

[35] KUROKOCHI, Y., SATO, M., "Properties of binderless board made from rice straw: The morphological effect of particles", Industrial Crops and Products, http://dx.doi.org/10.1016/j.indcrop.2015.01.044. v. 69, pp. 55-59, 2015.

[36] KABOORANI, A., "Characterizing water sorption and diffusion properties of wood/plastic composites as a function of formulation design", http://dx.doi.org/10.1016/j.conbuildmat.2016.12.120. Construction and Building Materials, v. 136, pp. 164-172, 2017.

[37] FERREIRA, A.S., NASCIMENTO, D.C.O., MONTEIRO, S.N., "Izod impact energy study of re-forced polisher matrix compounds with curaous fibers aligned and epoxy matrix reinforced with piassava fibers", http://dx.doi.org/10.1590/s1517-707620180004.0572. Matéria, v. 23, n. 4, 2018.

[38] LORANDI, N.P., CIOFFI, M.O.H., ORNAGHI JR., H., "Dynamic Mechanical Analysis (DMA) of Polymeric Composite Materials", https://doi.org/10.18226/23185279.v4iss1p48. Sci. cum Ind., v. 4, n. 3, pp. 4860, 2016.

[39] TAIPALE, T., ÖSTERBERG, M., NYKÄNEN, A., et al., "Effect of microfibrillated cellulose and fines on the drainage of kraft pulp suspension and paper strength", DOI 10.1007/s10570-010-9431-9. Cellulose, v. 17 , n. 5, pp. 1005-1020, 2010.

[40] KARAKUS, K., BIRBILEN, Y., MENGELOĞLU, F., “Assessment of selected properties of LDPE composites reinforced with sugar beet pulp", http://dx.doi.org/10.1016/j.measurement.2016.03.039. Measurement, v. 88, pp. 137-146, 2016.

[41] AL-MOHAMADAWI, A., BENHABIB, K., DHEILLY, R.M., et al., "Influence of lignocellulosic aggregate coating with paraffin wax on flax shive and cement-shive composite proper-

ties", http://dx.doi.org/10.1016/j.conbuildmat.2015.10.190. Const. Build. Mater., v. 102, pp. 94-104, 2016.

[42] PANAITESCU, I., KOCH, T., ARCHODOULAKI, V.M., "Effects of temperature, humidity and automotive fluids exposure on glass fiber/polyurethane composites", https://doi.org/10.1002/pc.25094. Polymer Composites, v. 6, pp. 2357-2367, 2019.

[43] SCIDA, D., ASSARAR, M., POILÂNE, C., et al., "Influence of hygrothermal ageing on the damage mechanisms of flax-fibre reinforced epoxy composite", http://dx.doi.org/10.1016/j.compositesb.2012.12.010. Comp. Part B, v. 48, pp. 51-58, 2013.

[44] SANTOS, R.P.O., RODRIGUES, B.V.M., SANTOS, D.M., et al., "Electrospun recycled PET-based mats: Tuning the properties by addition of cellulose and/or lig-

nin", http://dx.doi.org/10.1016/j.polymertesting.2017.04.023. Polym. Test., v. 60, pp. 422-431, 2017.

[45] HIDALGO-SALAZAR, M.A., MUNOZ, M.F., MINA, J.H., "Influence of corporation of natural fibers on the physical, mechanical, and thermal properties of composites LDPE-Al Reinforced with fique fibers", http://dx.doi.org/10.1155/2015/386325. Int. J. Polym. Sci., pp. 1-8, 2015.

[46] NABINEJAD, O., SUJAN, D., RAHMAN, M.E., et al., "Effect of filler load on the curing behavior and mechanical and thermal performance of wood flour filled thermoset compo-

sites", http://dx.doi.org/10.1016/j.jclepro.2017.07.036. J. Clean. Prod., v. 164, pp. 1145-1156, 2017.

[47] SAVAŞ, S., GURBANOV, N., DOĞAN, M., "Effect of fiber type, fiber content, and compatibilizer on two-body abrasive wear performance of HDPE matrix compo- 
sites", https://doi.org/10.1177/0021998319839135. Journal of Composite Materials, v. 19, pp. 2743-2760, 2019.

[48] GOLL, M.F.G.H. Produção e dimensionamento de uma unidade de obtenção de compósito de aparas de papel cartão com PET. 2016. Dissertação (Programa de Pós-Graduação em Engenharia Ambiental) - Universidade Regional de Blumenau, Blumenau. 2016.

[49] PĂRPĂRIŢĂ, E., DARIE, R.N., POPESCU, C. M., et al., "Structure-morphology-mechanical properties relationship of some polypropylene/lignocellulosic compo-

sites”, http://dx.doi.org/10.1016/j.matdes.2013.12.033. Materials \& Design, v. 56, pp. 763-772, 2014.

[50] MORTAZAVIAN, S., FATEMI, A., "Effects of fiber orientation and anisotropy on tensile strength and elastic modulus of short fiber reinforced polymer compo-

sites”, http://dx.doi.org/10.1016/j.compositesb.2014.11.041. Comp. Part B, v. 72, pp. 116-129, 2015.

[51] EFTEKHARI, M., FATEMI, A., "Tensile behavior of thermoplastic composites including temperature, moisture, and hygrothermal effects", https://doi.org/10.1016/j.polymertesting.2016.03.011. Polym. Test., v. 51, pp. 151-164, 2016.

[52] LOW, J.H., ANDENAN, N., RAHMAN, W.A., "The Influence of Crosslink Chemicals on the Mechanical Strength and Water Absorption of Rice Straw-Based Green Compo-

sites", http://www.tandfonline.com/doi/abs/10.1080/15440478.2017.1321514. J. Nat. Fibers, v. 15, n. 1, pp. 122-130, 2018.

[53] ZHANG, H., YAO, Y., ZHU, D., et al., "Tensile mechanical properties of basalt fiber reinforced polymer composite under varying strain rates and temperatures”, https://doi.org/10.1016/j.polymertesting.2016.02.006. Polym. Test., v. 51, pp. 29-39, 2016.

[54] YANG, H.S., "Thermal and dynamic mechanical thermal analysis of lignocellulosic material-filled polyethylene bio-composites", https://doi.org/10.1007/s10973-017-6572-1. J. Therm. Anal. Calorim., v. 130, n. 3, pp. 1345-1355, 2017.

[55] KALFUS, J., SINGH, N., LESSER, A.J., "Reinforcement in nano-filled PAA hydrogels", https://doi.org/10.1016/j.polymer.2012.02.057. Polymer, v. 13, pp. 2544-2547, 2012.

[56] CHEN, J., YAN, N., "Crystallization behavior of organo-nanoclay treated and untreated kraft fiberHDPE composites”, https://doi.org/10.1016/j.compositesb.2013.05.011. Comp. Part B, v. 54, pp. 180-187, 2013.

\section{ORCID}

Julia Santos Venzon

Atilano Antônio Vegini

Jackson Roberto Eleotório

Lorena Benathar Ballod Tavares https://orcid.org/0000-0002-9871-9114

https://orcid.org/0000-0002-7771-1199

http://orcid.org/0000-0001-5991-7153

https://orcid.org/0000-0001-7633-8196 


\section{SUPPLEMENTARY MATERIAL}

Table 2: Triplicate data from physical and mechanical tests obtained for LDPE composites reinforced with $10 \%$ and $20 \%$ PET-coated SBS paperboard shavings, according to temperature and particle size variations.

\begin{tabular}{|c|c|c|c|c|c|c|c|c|}
\hline TEMP. & GRAN. & CONC. & MOISTURE & ABSORPTION & DENSITY & IZOD IMPACT & TENSILE & FLEXURE \\
\hline 140 & 28 & 80 & 0.1757 & 0.5377 & 0.91 & 236.7509 & 6.56 & 14.78 \\
\hline 140 & 28 & 90 & 0.0758 & 0.2215 & 0.88 & 222.9 & 8.23 & 13.83 \\
\hline 140 & 28 & 100 & 0.0308 & 0.0249 & 0.9 & 307.5625 & 9.86 & 14.5 \\
\hline 140 & 14 & 80 & 0.4237 & 1.0956 & 0.9 & 279.5491 & 6.92 & 13.89 \\
\hline 140 & 14 & 90 & 0.1157 & 0.5946 & 0.9 & 258.6482 & 7.55 & 13.76 \\
\hline 140 & 14 & 100 & 0.0308 & 0.0249 & 0.9 & 290.5567 & 9.64 & 15.58 \\
\hline 140 & 5 & 80 & 0.9755 & 2.6587 & 0.86 & 322.2911 & 2.7 & 9.46 \\
\hline 140 & 5 & 90 & 0.2304 & 0.7774 & 0.85 & 247.6144 & 3.92 & 10.99 \\
\hline 140 & 5 & 100 & 0.0678 & 0.057 & 0.88 & 282.5509 & 9.42 & 17.18 \\
\hline 165 & 28 & 80 & 0.2746 & 0.6387 & 0.84 & 173.5907 & 5.29 & 13.53 \\
\hline 165 & 28 & 90 & 0.084 & 0.5899 & 0.79 & 186.27 & 7.34 & 13.5 \\
\hline 165 & 28 & 100 & 0.0307 & 0.0293 & 0.89 & 242.3833 & 9.66 & 14.22 \\
\hline 165 & 14 & 80 & 0.393 & 0.7924 & 0.92 & 203.4746 & 4.77 & 12.98 \\
\hline 165 & 14 & 90 & 0.1633 & 0.5922 & 0.8 & 228.8449 & 6.74 & 13.76 \\
\hline 165 & 14 & 100 & 0.0307 & 0.0234 & 0.87 & 248.5084 & 9.31 & 15.44 \\
\hline 165 & 5 & 80 & 0.7006 & 1.9431 & 0.83 & 252.6478 & 3.6 & 9.25 \\
\hline 165 & 5 & 90 & 0.2933 & 1.6909 & 0.96 & 201.6704 & 3.01 & 12.21 \\
\hline 165 & 5 & 100 & 0.0268 & 0 & 0.88 & 254.6334 & 8.96 & 16.66 \\
\hline 190 & 28 & 80 & 0.2884 & 1.2134 & 0.86 & 172.8349 & 4.69 & 7.54 \\
\hline 190 & 28 & 90 & 0.1267 & 0.282 & 0.72 & 148.7844 & 6.84 & 10.68 \\
\hline 190 & 28 & 100 & 0.026 & 0.0357 & 0.88 & 298.5892 & 8.59 & 12.8 \\
\hline 190 & 14 & 80 & 0.3454 & 1.4555 & 0.93 & 187.4049 & 4.42 & 7.09 \\
\hline 190 & 14 & 90 & 0.2072 & 0.6924 & 0.75 & 179.058 & 5.17 & 6.73 \\
\hline 190 & 14 & 100 & 0.0309 & 0.0016 & 0.89 & 286.0793 & 8.47 & 12.53 \\
\hline 190 & 5 & 80 & 0.9341 & 2.6059 & 0.75 & 176.9613 & 2.3 & 7.65 \\
\hline 190 & 5 & 90 & 0.3499 & 2.7412 & 0.87 & 174.8037 & 3.85 & 6.32 \\
\hline 190 & 5 & 100 & 0.0369 & 0.1256 & 0.84 & 273.5693 & 8.34 & 12.25 \\
\hline 140 & 28 & 80 & 0.1994 & 0.5234 & 0.91 & 236.6704 & 6.71 & 14.89 \\
\hline 140 & 28 & 90 & 0.0742 & 0.4343 & 0.91 & 223.9068 & 8.59 & 13.77 \\
\hline 140 & 28 & 100 & 0.0227 & 0.0038 & 0.9 & 310.0087 & 10.09 & 15.15 \\
\hline 140 & 14 & 80 & 0.5459 & 1.0081 & 0.94 & 281.1621 & 6.05 & 13.5 \\
\hline 140 & 14 & 90 & 0.1049 & 0.5895 & 0.92 & 255.0088 & 8.04 & 13.77 \\
\hline 140 & 14 & 100 & 0.024 & 0.0038 & 0.9 & 284.2257 & 10.05 & 15.6 \\
\hline 140 & 5 & 80 & 1.0841 & 2.9724 & 0.88 & 320.6986 & 2.76 & 9.79 \\
\hline 140 & 5 & 90 & 0.2311 & 0.8006 & 0.87 & 247.5126 & 4.52 & 10.35 \\
\hline 140 & 5 & 100 & 0.0391 & 0.0105 & 0.88 & 278.4428 & 10 & 16.05 \\
\hline 165 & 28 & 80 & 0.182 & 0.5259 & 0.92 & 175.6047 & 5.06 & 14.15 \\
\hline 165 & 28 & 90 & 0.0842 & 0.4152 & 0.89 & 187.3792 & 8.27 & 14 \\
\hline 165 & 28 & 100 & 0.0281 & 0.0038 & 0.9 & 241.3897 & 9.83 & 14.3 \\
\hline 165 & 14 & 80 & 0.4919 & 1.1677 & 0.93 & 204.4422 & 5.92 & 12.91 \\
\hline 165 & 14 & 90 & 0.1538 & 0.7143 & 0.91 & 229.8178 & 6.33 & 14.06 \\
\hline
\end{tabular}


Cont. Table 2.

\begin{tabular}{|c|c|c|c|c|c|c|c|c|}
\hline 165 & 14 & 100 & 0.0297 & 0.0176 & 0.9 & 250.9455 & 9.4 & 15.27 \\
\hline 165 & 5 & 80 & 1.1273 & 2.9486 & 0.83 & 253.3828 & 2.93 & 9.01 \\
\hline 165 & 5 & 90 & 0.3038 & 1.7709 & 0.9 & 199.5694 & 2.16 & 12.53 \\
\hline 165 & 5 & 100 & 0.0281 & 0.0675 & 0.85 & 256.5014 & 8.96 & 16.24 \\
\hline 190 & 28 & 80 & 0.4775 & 1.2477 & 0.77 & 170.207 & 4.37 & 7.33 \\
\hline 190 & 28 & 90 & 0.0909 & 0.7532 & 0.76 & 150.207 & 6.33 & 10.72 \\
\hline 190 & 28 & 100 & 0.0206 & 0.0386 & 0.9 & 299.7614 & 9.03 & 12.21 \\
\hline 190 & 14 & 80 & 0.4696 & 1.5274 & 0.81 & 186.5324 & 4.22 & 7.58 \\
\hline 190 & 14 & 90 & 0.1848 & 0.4878 & 0.65 & 178.097 & 5.33 & 7.16 \\
\hline 190 & 14 & 100 & 0.0219 & 0.0129 & 0.88 & 289.248 & 8.84 & 12.27 \\
\hline 190 & 5 & 80 & 0.9073 & 2.5502 & 0.76 & 175.4281 & 2.7 & 6.95 \\
\hline 190 & 5 & 90 & 0.4333 & 1.6945 & 0.8 & 175.4281 & 3.61 & 7.44 \\
\hline 190 & 5 & 100 & 0.0373 & 0 & 0.85 & 274.7346 & 8.65 & 12.32 \\
\hline 140 & 28 & 80 & 0.1614 & 0.5094 & 0.93 & 237.984 & 6.23 & 15.1 \\
\hline 140 & 28 & 90 & 0.0765 & 0.1557 & 0.9 & 221.721 & 8.37 & 13.2 \\
\hline 140 & 28 & 100 & 0.071 & 0.0425 & 0.9 & 300.2376 & 9.17 & 15.04 \\
\hline 140 & 14 & 80 & 0.2883 & 0.5623 & 0.91 & 279.1405 & 6.76 & 14.03 \\
\hline 140 & 14 & 90 & 0.104 & 0.5848 & 0.9 & 256.6714 & 7.15 & 13.27 \\
\hline 140 & 14 & 100 & 0.071 & 0.0436 & 0.9 & 292.188 & 9.58 & 15.84 \\
\hline 140 & 5 & 80 & 0.9654 & 2.3694 & 0.9 & 324.2418 & 3.04 & 9.12 \\
\hline 140 & 5 & 90 & 0.2443 & 0.7604 & 0.84 & 245.682 & 3.19 & 10.57 \\
\hline 140 & 5 & 100 & 0.0284 & 0.0316 & 0.9 & 288.1384 & 9.99 & 16.11 \\
\hline 165 & 28 & 80 & 0.1503 & 0.6003 & 0.96 & 173.5664 & 5.53 & 14.03 \\
\hline 165 & 28 & 90 & 0.0855 & 0.4459 & 0.83 & 185.3366 & 8.17 & 14.8 \\
\hline 165 & 28 & 100 & 0.0174 & 0.0425 & 0.91 & 243.4065 & 9.05 & 14.54 \\
\hline 165 & 14 & 80 & 0.4565 & 0.8195 & 0.92 & 201.5538 & 5.15 & 12.8 \\
\hline 165 & 14 & 90 & 0.1648 & 0.7615 & 0.74 & 227.495 & 5.85 & 14.91 \\
\hline 165 & 14 & 100 & 0.0187 & 0.0447 & 0.91 & 252.5801 & 8.98 & 15.61 \\
\hline 165 & 5 & 80 & 1.0644 & 2.8593 & 0.82 & 249.9077 & 3.06 & 9.42 \\
\hline 165 & 5 & 90 & 0.2997 & 1.8783 & 0.95 & 200.8923 & 2.27 & 11.99 \\
\hline 165 & 5 & 100 & 0.0293 & 0.0647 & 0.83 & 258.7538 & 8.9 & 16.68 \\
\hline 190 & 28 & 80 & 0.2503 & 1.2156 & 0.91 & 171.4319 & 4.31 & 7.26 \\
\hline 190 & 28 & 90 & 0.1491 & 0.4225 & 0.69 & 151.2875 & 6.72 & 11.74 \\
\hline 190 & 28 & 100 & 0.0235 & 0.0112 & 0.89 & 304.8963 & 7.92 & 12.24 \\
\hline 190 & 14 & 80 & 0.6893 & 1.5671 & 0.68 & 188.2046 & 4.77 & 7.08 \\
\hline 190 & 14 & 90 & 0.206 & 0.9359 & 0.58 & 178.6571 & 5.66 & 7.44 \\
\hline 190 & 14 & 100 & 0.0246 & 0.078 & 0.89 & 288.6591 & 8.17 & 12.12 \\
\hline 190 & 5 & 80 & 0.924 & 2.6396 & 0.75 & 177.3454 & 2.99 & 6.93 \\
\hline 190 & 5 & 90 & 0.4593 & 2.2116 & 0.74 & 174.5809 & 3.61 & 6.5 \\
\hline 190 & 5 & 100 & 0.0317 & 0 & 0.86 & 272.4219 & 8.42 & 12 \\
\hline
\end{tabular}

